\title{
Relationship between Communication Barriers and Stress in Parents with Deaf Children in Elementary Level Special Needs School in Pekanbaru
}

\author{
${ }^{1}$ Indah Damayanti, ${ }^{2}$ Sri Hadiati Purnamasari \\ ${ }^{1.2}$ Faculty of Psychology, State Islamic University Sultan Syarif Kasim of Riau, Pekanbaru, Riau
}

\begin{abstract}
Constraints in communication are generally experienced by parents with deaf children, especially in elementary school age. The inability of children to hear and the lack of vocabulary mastered by children causes difficulties in understanding and conveying messages between parents and children. This causes the need for parents to convey and receive messages from children not achieved perfectly and cause stress. This study aims to determine the relationship between barriers to communication with stress in parents who have deaf children at primary school level at SLBN (state special needs school) Pembina Pekanbaru. The method in this study uses a quantitative approach with correlational research design. This research is a population research, with the subject of the research are all parents who have deaf children at the elementary school level in the SLBN Pembina Pekanbaru, total 42 people. The data of this study were obtained using a scale of communication barriers revealed by researchers from the theory described by Fajar (2009) regarding the barriers to communication and stress scale revealed by researchers from the theory of Sarafino (1997) regarding stress and symptoms. The results of data analysis using the Product Moment correlation technique from Pearson through the help of the SPSS 24.0 for windows program showed a value of $r=0.819$ with a significant value $p=0.00$, meaning there is a positive relationship between communication barriers to stress in parents who have deaf children at primary school level in the SLBN Pembina Pekanbaru.
\end{abstract}

Keywords: communication barriers, stress, parents with deaf children.

\section{Research Background}

Humans are social beings who have the need and ability to communicate with others. Communication is a very important process in the life of a person. Through communication of a person or several people, groups, organizations, and communities create and use information to connect with the environment and others (Ruben and Stewart, 2006), one example of it is communication that occurs between parents and children.

Communication between parents and children is the most common communication, because parents are the closest figure to children. Parents have an important role in forming children's character and personality.

* Corresponding author: Indah Damayanti

indah.damayanti@uin-suska.ac.id

Published online at http://IJDS.ub.ac.id/2019- 1

Copyright @ 2019PSLD UB Publishing. All Rights Reserved
Another important role is helping children to develop their communication skills. Parents teach a child how to communicate with others both verbally and non-verbally. For example, when a child is still young, usually when breastfeeding, bathing, feeding, or when inviting his child to play, the mother will invite her child to talk or tell stories.

The important thing in communication between parents and children is how parents can communicate as effectively as possible. According to Tubss and Moss (in Mulyana, 2005), communication is said to be effective if people succeed in conveying what they mean or communication is considered effective if the stimulus delivered and intended by the sender or source is closely related to stimuli that are captured and understood by the recipient. Through effective communication parents are able to convey about their feeling and their thoughts, and vice versa with the child. But for 
parents who have deaf children with hearing limitations, communication between parents and children will tend to experience more obstacles.

Based on the experience of researchers who had taught at one of the special needs schools (SLB) in Pekanbaru, found obstacles and difficulties experienced by parents in communicating with deaf children, especially deaf children who are still in elementary school (SD). Based on observations and complaints submitted by parents to researchers, some barriers experienced by parents who have deaf children are parents complain that they often do not understand what is said by children, parents cannot use verbal communication through writing, because children cannot understand the meaning of writing and lack of mastery of vocabulary, and the biggest obstacle is that parents cannot convey messages and intentions to children because children do not understand what is conveyed by parents.

Research conducted by Negeri (2013) found that other difficulties in communicating caused differences in understanding between parents and children, this was also a difficulty experienced by subjects who had deaf children, namely difficulties in understanding children's desires. The inability to convey thoughts, feelings, ideas, needs and desires to others has an impact that needs are not perfectly satisfied (Indriyani, 2004). An unmet need and those needs can be physiological, psychological, social, environmental, developmental, spiritual, or cultural needs which are the trigger factors for stress (Potter and Perry, 2005).

Needs that are not satisfied perfectly due to barriers in communication affects the level of stress. Based on research conducted by Gunawati, Hartati and Listira (2006), the effectiveness of communication has a relationship with stress levels. The more effective communication is, the lower the stress level. This research is in line with the research conducted by Indrawati (2007) which concluded that communication skills affect the high and low levels of stress. Other studies also show that communication can affect stress levels, namely research conducted by Julianti and Yulia (2015). The results of these studies indicate a negative relationship between communication and stress levels. That is, the higher the individual's ability to communicate, the lower the level of stress experienced.
Communication is a process of delivering and receiving symbols that contain meaning, both in the form of information, thought, knowledge and others, from communicators to communicants. Communication is an important factor in interpersonal relations (Walgito, 2009). Lunandi (1992) states that communication is the activity of expressing an idea and receiving feedback by interpreting statements about other people's ideas and statements. Communication is not just conveying messages from communicators to communicants, but there is feedback for the message delivered.

According to Tubss and Moss (in Mulyana, 2005), communication is said to be effective if people succeed in conveying what they mean or communication is considered effective if the stimulus delivered and intended by the sender or source is closely related to stimuli that are captured and understood by the recipient. Effendy (2003) states that some communication experts say that it is impossible for someone to actually communicate effectively. There are many obstacles that can damage communication. Everything that hinders the smooth communication is called noise. DeVito (2009) states that communication barriers have the understanding that anything that can distort messages or anything that prevents recipients from receiving messages.

From the experts' understanding it can be concluded that communication barriers are all forms of disturbances that occur in the process of delivering and receiving a message from individuals to other individuals caused by environmental factors and physical and psychological factors of the individual itself.

According to Fajar (2009), there are several obstacles in communication, namely:

a. Obstacles from the sender of the message, for example the message to be conveyed is not clear to him or the sender of the message, this is influenced by feelings or emotional situations that influence motivation, namely encouraging someone to act according to their wants, needs or interests.

b. Barriers in encoding / symbols. This can happen because the language used is not clear so that it means more than one, the symbol used between the sender and the recipient is not same, or the language used is too difficult.

c. Media barriers are obstacles that occur in the use of communication media, such as radio 
sound interference so that they cannot listen to messages clearly.

d.Barriers in the language of passwords. Obstacles occur in interpreting the password by the recipient.

e. Obstacles from message recipients. For example, lack of attention when receiving / listening to messages, wrong attitudes / prejudices / responses and not seeking further information.

Wursanto (2005) summarizes communication barriers consisting of three types, namely:

\section{Technical barriers}

Technical barriers are obstacles caused by various factors, such as:

a. Lack of facilities and infrastructure needed in the communication process.

b.Mastery of inappropriate communication techniques and methods.

c. Physical conditions that do not allow the communication process to be divided into human physical conditions, physical conditions related to the time or situation / condition, and equipment conditions.

2) Semantic barriers

Obstacles caused by errors in interpreting, errors in understanding the language (words, sentences, codes) used in the communication process.

3) Behavioral barriers

Behavioral barriers are also called humanitarian barriers. Barriers caused by various forms of attitudes or behavior, both from communicators and communicants. Behavior barriers appear in various forms, such as:
a. A priori view
b. Prejudice based on emotions
c. Authoritarian atmosphere
d. Unwillingness to change
e. Egocentric nature

Bishop (1994) states that stress is the interaction between individuals and the environment, giving rise to pressure in the individual due to a demand that exceeds the limits of the individual's ability to deal with it and provide physical and psychological responses to perceived demands. This definition emphasizes the existence of demands on someone who exceeds his ability, and the perception process carried out by individuals to events or things in the environment that are a source of stress.
Stress is a condition of physical and psychological stress due to demands in self and the environment (Rathus \& Nevid, 2002). The statement means that a person can be said to experience stress, when a person experiences a condition of internal stress due to demands that come from within themselves and the environment.

Stress is a condition caused by transactions between individuals and their environment which creates a distance between demands originating from biological, psychological, and social system resources (Cox, 1978; Lazarus \& Folkman, 1984; Mechanic, 1976; Singer \& Davidson, 1986; Stotland, 1987; Trumbull \& Aplley, 1986 in Sarafino, 1997). Lazarus and Folkman (1984) define stress as a condition that appears to individuals when considering an event as a threatening and difficult.

From the understanding of the experts it can be concluded that stress is the body's response to demands from within themselves and the environment that exceeds the limits of individual abilities so that the stresses experienced by physical and psychological experiences occur.

There are two stress aspects according to Sarafino (1997), namely:

a. Biological aspects

The biological aspect of stress is physical symptoms. Physical symptoms of stress experienced by individuals include: headaches, nervousness, tense veins, sleep disorders, indigestion, eating disorders, skin disorders and excessive sweat production.

b. Psychological aspects

Psychological aspects of stress in the form of psychological symptoms. Psychological symptoms of stress include:

1) Symptoms of emotions

Stressful conditions can interfere with individual emotional stability. Individuals who experience stress will show symptoms of feeling sad, irritable, excessive anxiety about everything, and depression.

2) Cognitive symptoms

Stressful conditions can disrupt individual thought processes. Individuals who experience stress tend to experience decreased memory disorders, weakness in solving problems, fear of failure, impaired attention and concentration.

3) Behavioral symptoms 
Stress conditions can affect daily behavior that tends to be negative, causing problems in interpersonal relationships, such as withdrawing from family, losing interest, exploding emotions, and aggression.

From the findings of the problems in the field and analysis of the findings of related studies and existing theories, the researchers saw indications of a relationship between barriers to communication and stress in parents who have deaf children in the SDLBN Pembina Pekanbaru. For this reason, researchers conducted a study of these allegations.

\section{Method}

This study uses a quantitative correlational approach that connects the variable barriers to communication with stress in parents who have deaf children.

Variables of research. This study uses two variables, namely the $\mathrm{X}$ variable (communication barrier) as the independent variable and the $\mathrm{Y}$ variable (stress) as the dependent variable.

Research Population. The study population in this study were 42 parents who had deaf children at the SDLBN Pembina Pekanbaru.

Research sample. If the population is less than 100 , it is better to take it as a whole, so the research is population research. Furthermore, if the population is large than 100 , it can be taken between $10-15 \%$ or $20-30 \%$ or more (Arikunto, 2002). In this study, researchers took a whole sample of the population, namely 42 parents who have deaf children in the SDLBN Pembina Pekanbaru.

The sampling technique used is saturated sampling. According to Sugiyono (2013) saturated sampling is a technique of determining samples if all members of the population are used as samples. This is often done if the population is relatively small, where all members of the population are sampled.

The data collection technique in this study uses a psychological scale. In this study the researchers used two scales, namely the scale of communication barriers that researchers compiled from the theory of communication barriers from Fajar (2009) and stress scales derived from the theory of Sarafino (1997). Data were analyzed with the help of SPSS 24.0 for windows.

\section{Results}

This study aims to determine the relationship between communication barriers and stress in parents who have deaf children. Based on the results of the Product Moment correlation analysis, it was found that communication and stress barriers to parents who have deaf children at elementary school level in SDLBN Pembina Pekanbaru have a positive correlation, with a correlation coefficient (rxy) of 0.819 with a significant value of $0,000 \quad(\mathrm{p}<0,05)$. Positive correlation coefficient (rxy) indicates the direction of the relationship between the two variables. That is, the greater the communication barriers that occur between parents and children, the higher the level of stress in parents who have deaf children at primary school level in SDLBN Pembina Pekanbaru. On the contrary, the smaller the communication barriers that occur between parents and children, the lower the level of stress in parents who have deaf children at primary school level in SDLBN Pembina Pekanbaru. Thus the hypothesis in this study was accepted.

The results of the study which showed a relationship between communication and stress barriers were in accordance with the research conducted by Indriyani (2004) which stated that the inability to convey thoughts, feelings, ideas, needs and desires to other people caused an insatiable need for satisfaction which ended in feeling depressed or stressed.

Data categorization of communication barriers variable shows as many as 9 respondents $(21 \%)$ are in low categorization and 33 respondents $(79 \%)$ are in moderate categorization, it can be concluded that the majority of parents who have deaf children in SDLBN Pembina Pekanbaru have 
communication barriers in the moderate categorization. Constraints in communication can be in the form of misunderstanding of parents by words conveyed by children, sign language used by children is not understood by parents, children do not understand the message conveyed by parents, and lack of children's ability to hear, speak, and write which causes parents difficult to convey thoughts and feelings to children, and parents also have difficulty in understanding the thoughts and feelings of children. This is in line with the statement of Sastrawinata (in Negeri, 2013) which says that the inability of children to hear causes difficulties in communicating. Children who have hearing impairment are not able to capture messages through the voices of normal individuals, whereas normal individuals often do not understand how to deliver messages to children who are deaf.

Meanwhile, from the research data, the stress level of parents with deaf children in the SDLBN Pembina Pekanbaru is in the low category ( $43 \%$ ) to moderate (57\%), none of them are in the high stress category. This indicates that parents who have deaf children tend to experience physical and psychological stress, such as headaches, nervousness, tense veins, feeling sad, excessive anxiety, irritability, and decreased memory. The results of this study are in line with the results of Dogan (2010) study which shows that parents (especially mothers) who have children with hearing impairment have higher levels of stress, depression, and anxiety characteristics than parents of children with normal hearing. However, none of the parents of deaf children at the SDLBN Pembina Pekanbaru experienced severe stress.

The contribution of communication barriers to stress on parents who have deaf children is shown by the $\mathrm{R}$ value of 0.819 by adjusting $\mathrm{R} 2$ by 0.671 which means that the communication barriers have an effect of $67 \%$ on stress in parents who have deaf children. This means that $33 \%$ is influenced by other factors. Communication barriers are not the only factor that affects stress in parents who have deaf children. There are other factors such as parents' fear of the child's future as an adult, feeling inferior to the environment, and other factors that can affect stress in parents who have deaf children.

\section{Conclusion dan Future Works}

Based on data analysis regarding the relationship between barriers to communication with stress in parents who have deaf children at primary school level in special needs school (SDLBN) Pembina Pekanbaru, it can be concluded that there is a significant and positive relationship between barriers to communication with stress in parents who have deaf children at elementary school level in SLBN Pembina Pekanbaru with a correlation coefficient of $\mathrm{rxy}=$ $0.819, p=0,000$, where $p<0.01$. That is, the greater the communication barriers that occur between parents and children, the higher the level of stress in parents who have deaf children at the elementary school level in Pekanbaru Pembina SLBN. Contrarily, the smaller the communication barriers that occur between parents and children, the lower the level of stress in parents who have deaf children at primary school level in Pekanbaru Pembina SLBN. The level of relationship between the two variables is in the very strong category. The effective contribution of variable barriers to communication to stress is $67 \%$ and the remaining 33\% is influenced by other factors.

In this study researchers used quantitative methods, further research can also be done using qualitative methods to find out more about the barriers to communication with stress in parents who have deaf children so that they can enrich the results of the study.

\section{References}

Arikunto, Suharsini. (2002). Prosedur penelitian suatu pendekatan. Edisi Revisi V. Jakarta: Penerbit Rineka Cipta

Azwar, Saifuddin. (2010). Penyusunan skala psikologi. Yogyakarta: Penerbit Pustaka Pelajar

Cite this as:

Indah Damayanti, Sri H. Purnamasari. Relationship between Communication Barriers and Stress in Parents with Deaf Children in Elementary Level Special Needs School in Pekanbaru. Indonesian Journal of Disability Studies (IJDS).2019: Vol. 6(1): PP 14-20. 
Bishop, G. D. (1994). Health psychology: integrating mind and body. Singapore: Allin and Bacon.

DeVito, Joseph A. (2009). Komunikasi antarmanusia. Alih bahasa: Ir. Agus Maulana M.S.M. Tangerang: Karisma Publishing Group

Dogan, M. (2010). Comparison of the parents of children with and without hearing loss in terms of stress, depression, and trait anxiety. International Journal of early Childhood Special Education (INT-JECSE), 2:3

Efendi, Mohammad. (2006). Pengantar psikopedagogik anak berkelainan. Jakarta: Bumi Aksara

Effendy, Onong Uchjana. (2003). Ilmu, teori dan filsafat komunikasi. Bandung: PT. Citra Aditya Bakti.

Fajar, Marhaeni. (2009). Ilmu komunikasi teori dan praktek. Edisi Pertama. Yogyakarta: Graha Ilmu

Gunawati, Rindang, Sri Hartati dan Anita Listiara. (2006). Hubungan antara efektivitas komunikasi mahasiswa dan dosen pembimbing utama skripsi dengan stres dalam menyusun skripsi pada mahasiswa program studi psikologi Fakultas Kedokteran Universitas Diponegoro. Jurnal Psikologi Vol.3 No. 2, Desember 2006. Fakultas Psikologi, Universitas Diponegoro

Hadi, Sutrisno. (2004). Statistik. Yogyakarta: Penerbit Andi

Indrawati, Lisna. (2007). Hubungan antara keterampilan komunikasi interpersonal perawat dengan pasien dan stress kerja perawat. Skripsi. Yogyakarta: Fakultas Psikologi, Universitas Sanata Dharma

Indriyani, Faridah. (2004). Pengasuhan orang tua terhadap anak tunarungu (studi kasus di SLB Nurasih Ciputat). Skripsi. Jakarta: Fakultas Psikologi, UIN Syarif Hidayatullah

Julianti, Rina dan Aida Yulia. (2015). Hubungan komunikasi antara mahasiswa dan dosen pembimbing skripsi dengan stres dalam menyusun skripsi pada mahasiswa s1 keperawatan stikes ranah minang. Jurnal Ilmiah Ilmu Pendidikan Vol. XV No. 2, November
2015. Fakultas Ilmu Pendidikan, Universitas Negeri Padang

Lazarus, S. R. \&Folkman, Susan. (1984). Stress, appraisal, and coping. New York: Springer Publishing Company.

Lunandi, A.G. (1992). Meningkatkan efektivitas komunikasi antar pribadi. Yogyakarta: Kanisius

Margunsong, Frieda. (2009). Psikologi dan pendidikan anak berkebutuhan khusus. Depok: Lembaga Pengembangan Sarana Pengukuran dan Pendidikan Psikologi (LPSP3) Fakultas Psikologi Universitas Indonesia (FPUI)

Mulyana, Dedi. (2005). Ilmu Komunikasi : Suatu Pengantar. Bandung : Remaja Rosda Karya

Negeri, Citra Bunga. (2013). Subjective well being pada ibu yang memiliki anak tuna rungu. Jurnal Ilmiah Mahasiswa Universitas Surabaya Vol.2 No.2. Fakultas Psikologi, Universitas Surabaya

Potter, P.A dan Perry. (2005). Buku ajar fundamental keperawatan konsep, proses, dan praktik. Edisi 4. Jakarta: EGC

Putry, Dian Andhyka. (2013). Aktivitas komunikasi orang tua dengan anak tunarungu (studi kasus aktivitas komunikasi verbal dan nonverbal orang tua dengan anak tunarungu di SLB Negeri 017700 Kota Kisaran). Jurnal Ilmu Komunikasi Vol.1 No.3. Fakultas Ilmu Komunikasi, Universitas Sumatera Utara

Rathus, S. A. \& Nevid, J. S. (2002). Psychology and the challenge of life: adjustment in the new millenium. Eight Edition. Danver: John Willey \& Sons, Inc.

Ruben, Brent D \& Lea P. Steward. (2006). Komunikasi dan perilaku manusia. Jakarta : PT. Rajagrafindo Persada

Sarafino, E.P. (1997). Health Psychology. Third Edition. Canada: John Wiley \& Sons.

Sinaga, Deniaty. (2015). Pola komunikasi orang tua tunarungu dengan anaknya yang memiliki pendengaran normal. Yogyakarta: Fakultas Ilmu Pendidikan, Pendidikan Luar Biasa, Universitas Pendidikan Indonesia. 
Smet, Bart. (1994). Psikologi kesehatan. Jakarta: Gramedia Widiasarana Indonesia.

Somantri, Sutjihati T. (2007). Psikologi anak luar biasa. Bandung: Refika Aditama

Sugiyono. (2013). Metode penelitian kuantitatif, kualitatif, dan R\&D. Bandung : Alfabeta

Sugiyono. (2011). Statistika untuk penelitian. Bandung: Penerbit Alfabeta

Sahetapy, Surya. (2012). Kaum tuli menuntut akses pendidikan. Diunduh dari: http://www.suryasahetapy.com/2012/10/kaumtuli-menuntut-akses-pendidikan.html.
Syatriani, Revi. (2011). Hubungan antara kemampuan komunikasi dengan kemandirian pada remaja tunarungu. Skripsi. Fakultas Psikologi, Universitas Gunadarma

Variani, Ludfia Ida. (2011). Pelatihan sistem isyarat bahasa indonesia (sibi) terhadap peningkatan kemampuan komunikasi orang tua dengan anak tunarungu. Ringkasan Tesis. Malang: Fakultas Psikologi, Universitas Muhammadiyah Malang

Walgito, Bimo. (2010). Pengantar psikologi umum. Yogyakarta: C.V. Andi Offset

Wursanto, I. (2005). Dasar-dasar ilmu organisasi. Yogyakarta: CV. Andi Offset. 